\title{
Kelimpahan dan Keanekaragaman Tunikata (Ascidiacea) di Perairan Jemeluk dan Penuktukan, Bali
}

\author{
Ni Made Pitria Menala Saputri ${ }^{a}{ }^{*}$ I Dewa Nyoman Nurweda Putra a, Widiastuti a \\ a Program Studi Ilmu Kelautan, Fakultas Kelautan dan Perikanan, Universitas Udayana, Kampus UNUD Bukit Jimbaran, Bali 80361, Indonesia \\ *Penulis koresponden. Tel.: +62-812-368-708-69 \\ Alamat e-mail: pitria0202@gmail.com
}

Diterima (received) 10 Oktober 2017; disetujui (accepted) 2 Februari 2018; tersedia secara online (available online) 5 Februari 2018

\begin{abstract}
Tunikata is an animal shaped like a tube and its body is covered by a mantle (tunic). These organisms have functions and impacts for ecology, pharmacology, people and the economy. However, the various important roles of the tunicate are not matched by information on abundance and diversity in Indonesia in general and the island of Bali in particular. Therefore, this study aims to determine the abundance, species composition and the diversity of tunikata in the waters of Jemeluk and Penuktukan, Bali, where each of these waters has a different coral reef morphology reef flats (Jemeluk) and reef slopes (Penuktukan). Data retrieval is done with a $25 \times 2 \mathrm{~m}^{2}$ belt transect and parallel to the shoreline. Determination of location of observation based on purposive sampling method. Analysis of the data used using the abundance formula, species composition and the Shannon-Wiener diversity index. The results showed that the abundance of tunikata in Jemeluk waters did not differ significantly between stations where the highest was found in stations 1 and 3, the lowest at station 2. But the abundance of tunicates in waters Penuktukan significantly different between stations where the highest in three and the lowest station on Station 1 . There are nine kinds of tunicates on both waters where species Didemnum molle and Atriolum robustum is the type most commonly found. The highest diversity of tunicate species in Jemeluk waters is found in stations 1 and 3 and the lowest is at station 2, while the highest Penuktukan is located at station 1 and the lowest is at station 3 . In general, the index of biodiversity in both waters is categorized as low.
\end{abstract}

Keywords: Tunikata; Abundance; Species composition Speciesdiversi; Jemeluk; Penuktukan

\begin{abstract}
Abstrak
Tunikata merupakan hewan berbentuk seperti tabung dan tubuhnya tertutupi oleh mantel (tunic). Organisme ini memiliki fungsi dan dampak bagi ekologi, farmakologi, manusia dan perekonomian. Namun, berbagai peranan penting tunikata tersebut tidak diimbangi dengan informasi mengenai kelimpahan dan keanekaragaman di Indonesia pada umumnya dan pulau Bali pada khususnya. Oleh sebab itu penelitian ini bertujuan untuk mengetahui kelimpahan, komposisi jenis dan keanekaragaman tunikata di perairan Jemeluk dan Penuktukan, Bali, dimana masing-masing perairan ini memiliki bentuk morfologi terumbu yang berbeda yaitu rataan terumbu (Jemeluk) dan lereng terumbu (Penuktukan). Pengambilan data dilakukan dengan Belt transect berukuran 25x2 $\mathrm{m}^{2}$ sejajar garis pantai. Penentuan lokasi pengamatan didasarkan metode purposive sampling. Analisis data yang digunakan menggunakan rumus kelimpahan, komposisi jenis dan indek keanekaragaman Shannon-Wiener. Hasil pengamatan menunjukkan bahwa kelimpahan tunikata di perairan Jemeluk tidak berbeda signifikan antar stasiun dimana tertinggi terdapat pada stasiun 1 dan 3 dan terendah pada stasiun 2. Tetapi kelimpahan tunikata di perairan Penuktukan berbeda nyata antar stasiun dimana tertinggi terdapat pada stasiun 3 dan terendah terdapat pada stasiun 1. Terdapat 9 jenis tunikata pada kedua perairan dimana jenis Didemnum molle dan Atriolum robustum merupakan jenis yang paling banyak ditemukan. Keanekaragaman jenis tunikata di perairan Jemeluk tertinggi terdapat pada stasiun 1 dan 3 dan terendah terdapat pada stasiun 2, sedangkan di perairan Penuktukan tertinggi terdapat pada stasiun 1 dan terendah terdpat pada stasiun 3. Secara umum, indeks keanekaragaman tunikata di kedua perairan dikategorikan rendah.
\end{abstract}

Kata Kunci: Tunikata; Kelimpahan; Komposisi jenis; Keanekaragaman jenis; Perairan Jemeluk ; Perairan Penuktukan 


\section{Pendahuluan}

Tunikata (Ascidian) merupakan hewan yang termasuk dalam subfilum Urochrodata, yang memiliki bentuk tubuh seperti kantong berukuran kecil dan umumnya hidup di perairan laut. Tubuh hewan ini ditutupi oleh mantel (tunic) yang terbentuk dari senyawa protein dan polisakarida, sehingga kelompok hewan ini diberi nama "Tunikata". Tunikata merupakan organisme yang bersifat filter feeder yaitu organisme yang mendapatkan makanan dengan cara menyaring (Brodie et al., 2011).

Beberapa spesies tunikata memiliki manfaat yang sangat besar dalam kehidupan manusia maupun lingkungan, seperti mengandung senyawa antibiotik (Da Rocha, 2015; Lambert et al., 2016), tetapi keberadaan tunikata yang berlebih memiliki pengaruh yang negatif, seperti tunikata yang bersifat filter feeder akan mengambil makanan yang dibutuhkan oleh hewan yang ditempeli atau hidup di dekatnya, selain itu tunikata menempel pada lambung kapal yang akan menambah bobot kapal sehingga terjadi pemborosan bahan bakar (Gewing, 2016), kemampuan hewan ini untuk menyebar dari satu tempat ke tempat lain dan beradaptasi dengan lingkungan baru secara cepat antara lain melalui transportasi kapal, menyebabkan spesies tertentu menjadi invasive hingga mendominasi dan mengancam keberadaan organisme asal (Ali et al, 2014; Hirose et al., 2009).

Tunikata merupakan salah satu komponen komunitas terumbu karang yang hidupnya sesil di terumbu, substrat dan batu (Lambert, 2010). Bentuk morfologi terumbu karang terdiri atas lagoon, rataan terumbu (reef flat), lereng terumbu (reef slope), dan fore-reef dimana zona-zona tersebut tidak selalu ditemukan pada suatu perairan laut dan dapat bervariasi antar perairan (Gischler, 2010). Perbedaan kondisi hidrodinamika yang berbeda seperti paparan gelombang, pasang surut dan sedimentasi dapat mempengaruhi struktur komunitas yang hidup di zona-zona tersebut (Morrissey, 1980).

Pengetahuan mengenai kelimpahan dan keanekaragaman jenis tunikata di Indonesia khususnya di Bali, tidak sebanding dengan fungsi ekologis dan ekonomi tunikata, sehingga mendorong perlunya penelitian mengenai struktur komunitas tunikata di perairan Bali yang memiliki morfologi terumbu yang berbeda. Penelitian ini bertujuan untuk mengetahui kelimpahan, komposisi jenis dan keanekaragaman tunikata pada perairan Jemeluk yang memiliki zona rataan terumbu dan perairan Penuktukan yang memiliki zona lereng terumbu.

\section{Metode Penelitian}

\subsection{Waktu dan Tempat}

Penelitian ini dilakukan selama 2 hari pada tanggal 15-16 maret di perairan Jemeluk, Kabupaten Karangasem dan 2 hari pada tanggal 24-25 April 2017 di perairan Penuktukan, Kabupaten Buleleng, provinsi Bali (Gambar 1).

\subsection{Pengambilan Data Tunikata}

Stasiun penelitian ditentukan berdasarkan metode purposive sampling dan terletak sejajar garis pantai. Terdapat masing-masing 3 stasiun dan 3 kali pengulangan pada setiap perairan. Pengambilan data tunikata dilakukan secara visual sensus pada kedalaman 4-10 m menggunakan metode transek sabuk (belt transect) dengan ukuran $25 \times 2 \mathrm{~m}^{2}$ (Gambar 2).

Tunikata yang ditemukan lalu dicatat dan didokumentasikan menggunakan kamera bawah air untuk selanjutnya diidentifikasi berdasarkan Tropical Pacific Invertebrates (Colin et al, 1995). Selain data tunikata, data parameter perairan juga diukur seperti suhu, salinitas, kecerahan, kedalamn dan kecepatan arus juga diukur. Pengukuran data suhu, salinitas dan $\mathrm{pH}$ diperoleh dengan cara mengambil sampel air yang diambil $\pm 1 \mathrm{~m}$ di atas komunitas tunikata. Sedangkan kecepatan arus diukur pada arus permukaan, lalu dihitung menggunakan persamaan 1 dan disesuaikan dengan skala kecepatan arus (Tabel 1):

$V=\frac{s}{t} \mathrm{Z}$

dimana $V$ adalah kecepatan arus $(\mathrm{m} / \mathrm{s}) ; s$ adalah jarak atau panjang tali (m); dan $t$ adalah waktu tempuh (s).

Definisi morfologi terumbu yang digunakan dalam penelitian ini yaitu : zona rataan terumbu (reef flat) yaitu zona terumbu karang yang menunjukkan bentuk permukaan dasar (geomorfologi) relatif datar sedangkan zona lereng terumbu (reef slope) yaitu zona terumbu karang 


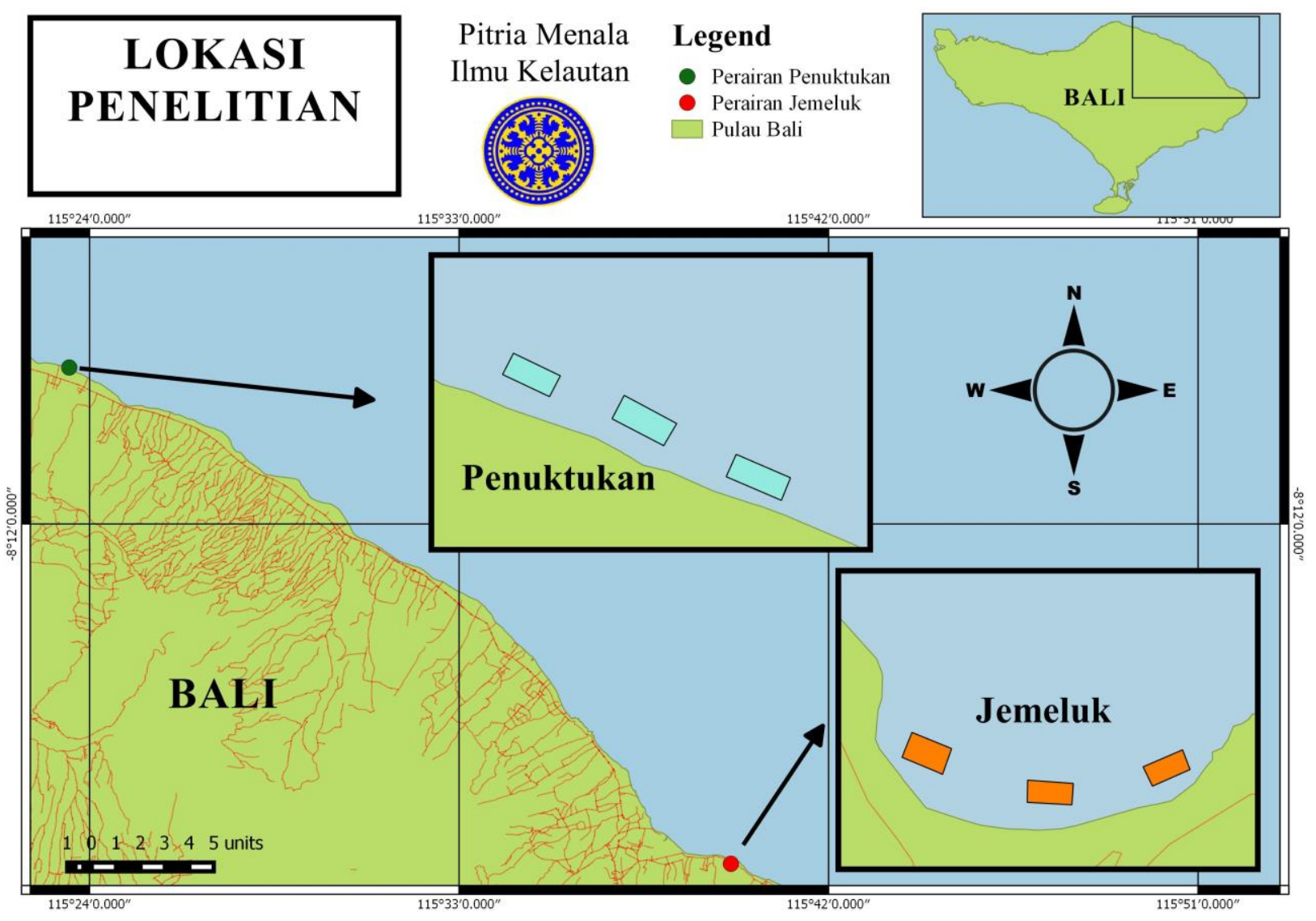

Gambar 1. Peta Lokasi Penelitian di perairan Jemeluk dan Penuktukan

yang menunjukkan bentuk permukaan dasar seperti lereng/miring (Gambar 3) (Morrissey, 1980).

\section{Tabel 1}

Skala kecepatan arus (Mason, 1981).

\begin{tabular}{cc}
\hline Skala $\mathbf{( c m} / \mathbf{s})$ & Keterangan \\
\hline 100 & Sangat cepat \\
$50-100$ & Cepat \\
$25-50$ & Sedang \\
$<10$ & Lambat \\
\hline
\end{tabular}

\subsection{Analisis Data}

\subsubsection{Kelimpahan Tunikata}

Kelimpahan dinyatakan dalam jumlah koloni per satuan transek (koloni/transek). Menurut Collen et al (2009), perhitungan kelimpahan jenis di tentukan dengan rumus sebagai berikut:

$D i=\frac{N i}{A}$

dimana $D i$ adalah jumlah individu ke-i persatuan luas; $N i$ adalah jumlah individu ke-i; dan $A$ adalah luasan transek $=50 \mathrm{~m}^{2}$.

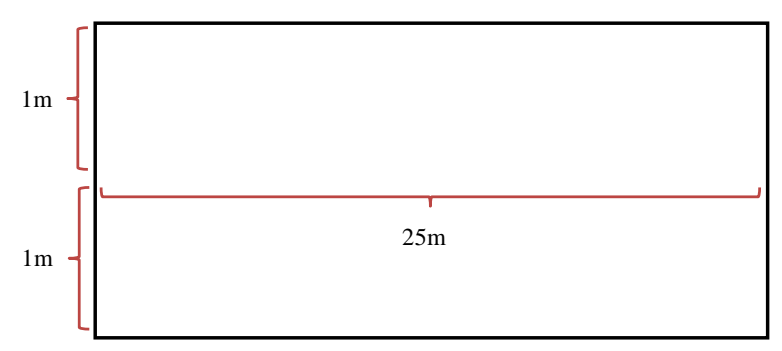

Gambar 2. Transek pengambilan data.

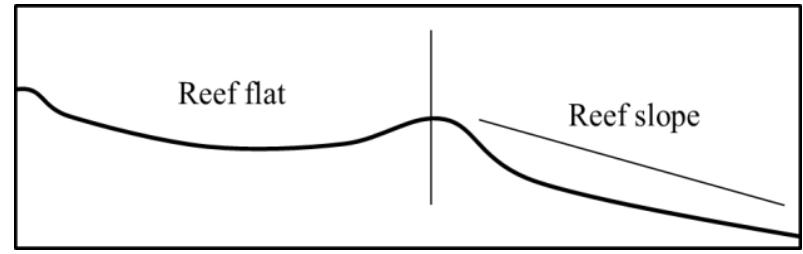

Gambar 3. Karakteristik lokasi penelitian

\subsubsection{Uji Statistik}

Data yang didapat di uji normalitasnya, apabila data menunjukkan distribusi tidak normal maka di lakukan tranformasi data, apabila transformasi data kembali tidak menunjukkan distribusi normal 
maka data dianalisis dengan uji non parametrik. Uji non parametrik merupakan uji yang tidak mensyaratkan bentuk sebaran parameter populasi terdistribusi normal, digunakan menganalisis data yang berskala nominal atau ordinal dan umumnya digunakan untuk data berjumlah kecil $(n<30)$ (Djarwanto. 1991). Dalam perhitungan uji statistik non parametrik di bantu menggunakan software statistik untuk medapatkan hasil.

Uji statistik yang digunakan untuk mengetahui adanya perbedaan kelimpahan antar lokasi pengamatan menggunakan uji statistik Mann Whitney. Uji Mann Whitney Test digunakan untuk menguji hipotesis komparatif dua sampel independen bila datanya berbentuk ordinal. Menurut Sugiyono (2006), uji Mann-Whitney menggunakan rumus :

$U_{1}=n_{1} n_{2}+\frac{n_{1}\left(n_{1}+1\right)}{2}-R_{1}$

$U_{2}=n_{1} n_{2}+\frac{n_{2}\left(n_{2}+1\right)}{2}-R_{2}$

dimana $\mathrm{n}_{1}$ adalah kelimpahan tunikata di perairan Jemeluk (reef flat); n2 adalah kelimpahan tunikata di perairan Penuktukan (reef slope ; $\mathrm{U}_{1}$ adalah jumlah peringkat $1 ; \mathrm{U}_{2}$ adalah jumlah peringkat 2; $\mathrm{R}_{1}$ adalah jumlah ranking pada sampel $\mathrm{n}_{1}$; dan $\mathrm{R}_{2}$ adalah jumlah ranking pada sampel n2.

Dalam menentukan $R_{1}$ dan $R_{2}$ dilakukan perankingan data kelimpahan pada masingmasing sampel $\mathrm{n}_{1}$ dan $\mathrm{n}_{2}$ dengan cara mengurutkan dari nilai kelimpahan yang terkecil hingga terbesar lalu di urutkan menggunakan angka. Kedua rumus tersebut digunakan dalam perhitungan untuk mengetahui nilai $U$ mana yang lebih kecil, nilai U yang lebih kecil akan digunakan untuk pengujian dan membandingkan dengan $\mathrm{U}$ Tabel. Hipotesis yang digunakan yaitu: $\mathrm{H}_{0}$ : Tidak terdapat perbedaan kelimpahan pada Perairan Jemeluk dan Penuktukan; $\mathrm{H}_{1}$ : Terdapat perbedaan kelimpahan pada Perairan Jemeluk dan Penuktukan.

Sedangkan untuk menguji perbedaan dari ketiga stasiun di masing-masing lokasi menggunakan uji Friedman. Uji Friedman digunakan untuk menguji hipotesis komparatif $\mathrm{k}$ sampel yang berpasangan, bila datanya berbentuk ordinal (ranking). Jika data berbentuk rasio makan di ubah menjadi data ordinal sehingga akan terbentuk distribusi Chi Kuadrat, maka rumus yang digunakan adalah rumus Chi Kuadrat $\left(X^{2}\right)$ (Sugiyono, 2006):

$x^{2}=\frac{12}{N k(k+1)} \sum_{j=1}^{k}\left(R_{j}\right)^{2}-3 N(k+1)$

dimana $N$ adalah banyak baris dalam Tabel; $k$ adalah banyak kolom; $R j$ adalah jumlah ranking dalam kolom.

Baris dalam Tabel mewakili banyaknya stasiun yang digunakan, sedangkan kolom mewakili kelimpahan pada setiap stasiun. Hipotesis yang digunakan yaitu $\mathrm{H}_{0}$ : Ketiga stasiun pengamatan memiliki kelimpahan yang sama; $\mathrm{H}_{1}$ : Ketiga stasiun pengamatan memiliki kelimpahan yang berbeda.

Apabila terdapat perbedaan signifikan terhadap kelimpahan rata-rata antar stasiun, maka dilakukan uji lanjut Sign Test dengan bantuan untuk mengetahui stasiun mana yang memberikan perbedaan. Uji Sign Test adalah untuk menguji hipotesis komparatif dua sampel yang berkorelasi, bila data berbentuk ordinal. Uji tanda didasarkan atas tanda-tanda positif dan negatif dari perbedaan antara data pengamatan (Sugiyono, 2006). Uji ini digunakan untuk membedakan kelimpahan di masing-masing stasiun. Hipotesis yang di gunakan dalam uji ini yaitu $\mathrm{H}_{0}$ : Tidak terdapat perbedaan rata-rata kelimpahan dari ketiga stasiun penelitian; $\mathrm{H}_{1}$ : Terdapat perbedaan rata-rata kelimpahan dari ketiga stasiun penelitian. Kriteria penolakan dan penerimaan Ho yaitu Jika $\mathrm{h}_{\text {hit }}>\mathrm{a}=\mathrm{h} 0$ ditolak; dan Jika hhit $<\mathrm{a}=\mathrm{h} 0$ diterima

\subsubsection{Komposisi Jenis}

Komposisi jenis tunikata dikelompokan menurut stasiun dan dianalisis secara deskriptif dengan menggunakan Tabel dan grafik. Dalam menghitung komposisi jenis tunikata digunakan rumus (Collen et al, 2009) :

$\frac{n i}{N} \times 100 \%$

dimana $n i$ adalah jumlah individu setiap jenis; dan $N$ adalah jumlah total individu.

\subsubsection{Komposisi Jenis}

Indeks Keanekaragaman dihitung dengan menggunakan rumus "Shannon Index of Diversity" (Collen et al, 2009). Kategori Indek 
Keanekaragaman Shanon-Wiener ditampilkan pada (Tabel 2)

$H^{\prime}=-\sum \frac{n i}{N} \ln \frac{n i}{N}$

dimana $H^{\prime}=$ Indeks Keanekaragaman; $N i$ adalah jumlah individu setiap spesies; $N$ adalah jumlah individu seluruh spesies.

Tabel 2

Kategori Indeks Keanekaragaman Shannon-Wiener (Collen et al, 2009)

\begin{tabular}{ll}
\hline \multicolumn{1}{c}{$\begin{array}{c}\text { Indeks Keanekaragaman } \\
\left(\mathbf{H}^{\prime}\right)\end{array}$} & Kategori \\
\hline $\mathrm{H}^{\prime}<1,0$ & Rendah \\
$1,0<\mathrm{H}^{\prime}<3,322$ & Sedang \\
$\mathrm{H}^{\prime}>3,322$ & Tinggi \\
\hline
\end{tabular}

\section{Hasil dan Pembahasan}

\subsection{Parameter Lingkungan}

Hasil pengukuran parameter perairan pada perairan Jemeluk dan perairan Penuktukan ditampilkan pada Tabel 3. Suhu di perairan Jemeluk memiliki kisaran rata-rata antar stasiun yang tidak jauh berbeda, dimana suhu terendah terdapat pada stasiun 2 yang merupakan satusatunya stasiun yang terdapat aliran sungai. Selain itu, sehari sebelum pengambilan data terjadi hujan yang memungkinkan suhu perairan menjadi lebih rendah dibandingkan stasiun lainnya. Suhu perairan Penuktukan juga memiliki kisaran rata antar stasiun yang tidak jauh berbeda. Suhu di stasiun 1 paling tinggi karena pengambilan data dilakukan pada siang hari sedangkan pada stasiun 2 dan 3 dilakukan pada siang menuju sore hari. Menurut Affan (2012), suhu air permukaan di perairan Indonesia umumnya berkisar antara 28310C, dimana hal tersebut dipengaruhi oleh kondisi meteorologi seperti curah hujan, penguapan, kelembaban udara, suhu udara, kecepatan angin dan intensitas matahari.

Derajat keasaman $(\mathrm{pH})$ di kedua pantai menunjukkan kisaran rata-rata yang tidak jauh berbeda. Kandungan $\mathrm{pH}$ di Perairan Jemeluk bervariasi 0.1 antar stasiun dibandingkan dengan Perairan Penuktukan yang cenderung homogen. Menurut Rukminasari (2016) pH air laut cenderung bersifat konstan. Kandungan $\mathrm{pH}$ pada
Perairan Jemeluk dan Penuktukan masih normal untuk hewan seperti tunikata. Menurut Radhalakshmi (2014), kandungan pH yang cocok untuk jenis hewan laut termasuk jenis tunikata berkisar antara 6,7-8,6\%

\section{Tabel 3}

Parameter fisika dan kimia di masing-masing stasiun pada Perairan Jemeluk dan Perairan Penuktukan.

\begin{tabular}{lccccccc}
\hline \multirow{2}{*}{ Parameter } & $\begin{array}{c}\text { Satu- } \\
\text { an }\end{array}$ & \multicolumn{3}{c}{ Jemeluk } & \multicolumn{4}{c}{ Nilai } \\
& & 1 & 2 & 3 & 1 & 2 & 3 \\
\hline Suhu & ${ }^{0} \mathrm{C}$ & 28 & 27 & 28 & 30 & 29 & 29 \\
$\mathrm{pH}$ & - & 8.0 & 8.4 & 8.5 & 8.5 & 8.5 & 8.5 \\
Kecerahun & $\mathrm{m}$ & 86 & 93 & 88 & 94 & 97 & 97 \\
Arus & $\mathrm{cm} / \mathrm{s}$ & 2.3 & 3.1 & 3.4 & 3.4 & 4.4 & 5.1 \\
Salinas & $\mathrm{ppt}$ & 29 & 29 & 29 & 29 & 30 & 30 \\
Kedalaman & $\mathrm{m}$ & 5.7 & 3 & 2.7 & 6 & 4 & 3.3 \\
\hline
\end{tabular}

Tingkat kecerahan di perairan Jemeluk terendah terdapat pada stasiun 3 dan tertinggi terdapat pada stasiun 2, dimana hal ini dipengaruhi oleh cuaca saat pengambilan data yang tidak menentu (cerah berawan).Sebaliknya, tingkat kecerahan di perairan Penuktukan tidak jauh berbeda pada tiap stasiunnya, hal ini dipengaruhi oleh arus dan ombak yang mengaduk sedimen dasar perairan. Menurut Roberts et al., (2010), menyatakan bahwa kecerahan di dasar perairan dipengaruhi oleh padatan tersuspensi, seperti lumpur dan jasad renik serta warna air.

Kecepatan arus permukaan di perairan Jemeluk terendah terdapat pada stasiun 1 dan tertinggi terdapat pada stasiun 3. Perairan Jemeluk merupakan daerah berbentuk teluk sehingga perairannya cukup terlindung dan pengaruh angin tidak terlalu berpengaruh besar. Kecepatan arus di perairan Penuktukan terendah terdapat pada stasiun 1 dan tertinggi pada stasiun 3.Letak perairan Penuktukan yang terbuka menyebabkan pengaruh angin sangat berpengaruh terhadap arus dan gelombang di perairan tersebut. Kisaran kecepatan arus permukaan di kedua perairan menunjukkan kecepatan arus sangat lambat (Tabel 1).

Salinitas di perairan Jemeluk secara rata-rata tidak jauh berbeda antar stasiunnya kecuali di stasiun 2 dimana lebih rendah karena adanya masukan air tawar ke perairan. Nilai salinitas di perairan Penuktukan memiliki rata-rata salinitas yang tidak jauh berbeda tiap stasiunnya dimana tertinggi terdapat pada stasiun 2 karena waktu 
pengambilan data yang dilakukan pada siang hari. Menurut Kott et al (2009) tunikata dapat hidup pada kisaran salinitas 30-32 ppt.

Kedalaman di Perairan Jemeluk tertinggi pada stasiun 1 dan terendah pada stasiun 3, sedangkan pada Penuktukan tertinggi terdapat pada stasiun 1 dan terendah pada stasiun 3. Menurut Poore et al. (2015), jenis dan sebaran biota tunikata dibatasi oleh sebaran vertikal (kedalaman) dan horizontal pada kondisi habitat yang berbeda. Menurut Sala et al. (2012) tunikata lebih melimpah pada kedalaman $10 \mathrm{~m}$.

\subsection{Kelimpahan Tunikata}

Terdapat 10 jenis tunikata yang ditemukan pada kedua perairan, dimana dari hasil uji statistik Mann Whitney dengan selang kepercayaan 95\% ( $a=0.05)$, didapatkan hasil $\mathrm{P}_{\text {hit }}>\mathrm{a}$ dimana $\mathrm{H}_{0}$ di tolak yang berarti terdapat perbedaannya nyata antara kelimpahan di Perairan Jemeluk dan Penuktukan. Secara rata-rata ditemukan 9 jenis tunikata di Perairan Jemeluk yaitu Didemnum molle (2a), Atriolum robustum (2b), Polycarpa aurata (2c), Polycarpa papillata (2d), Polycarpa sp. (2e), Phallusia sp 01. (2f), Phallusia sp 02. (2g), Rhopalaea sp. (2h) dan Didemnum sp. (2i), (Gambar 2) dimana jenis Rhopalaea sp. (2h) hanya ditemukan di Perairan Jemeluk.

Kelimpahan rata-rata tunikata yang ditemukan di Perairan Jemeluk ditunjukkan pada Gambar 3 dimana kelimpahan tertinggi terdapat pada stasiun 1 dan 3, sedangkan terendah pada stasiun 2. Hasil uji statistik Friedman dengan selang kepercayaan 95\% ( $a=0.05)$, didapatkan hasil $P_{h i t}<a$ dimana H0 di terima yang berarti tidak terdapat perbedaan kelimpahan jenis tunikata antar ketiga stasiun.
$2 a$.

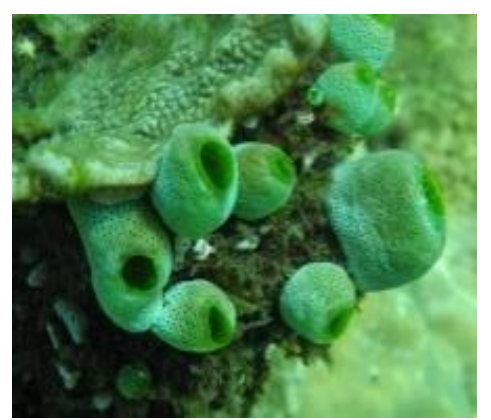

$2 \mathrm{~d}$.

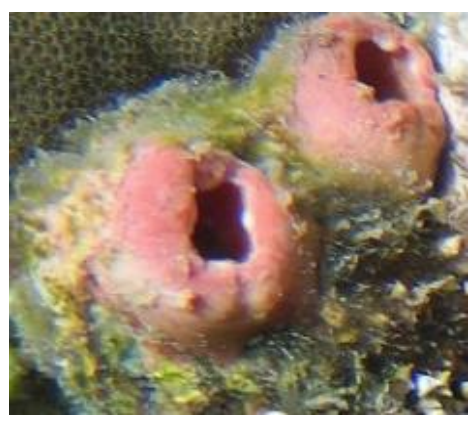

$2 \mathrm{~g}$.

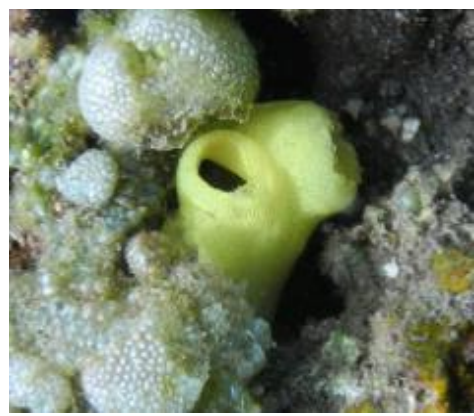

$2 b$.

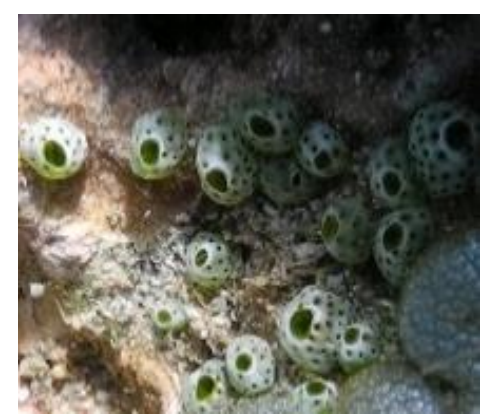

$2 e$.

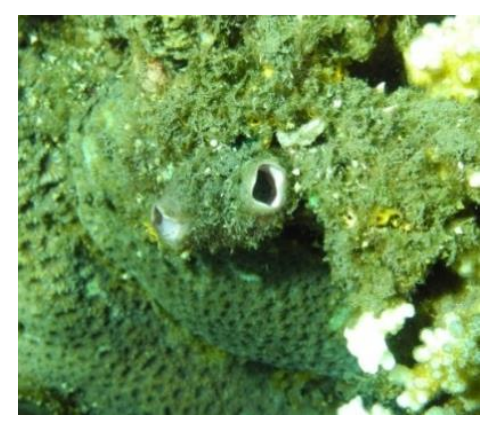

2.h

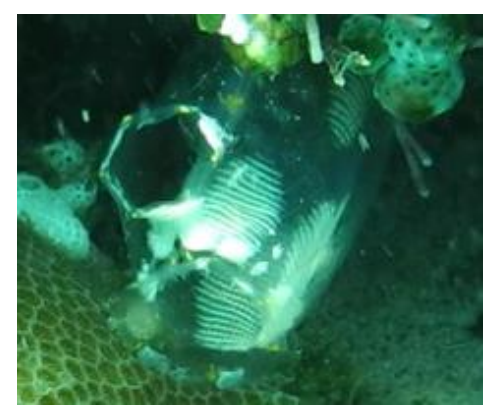

2c.

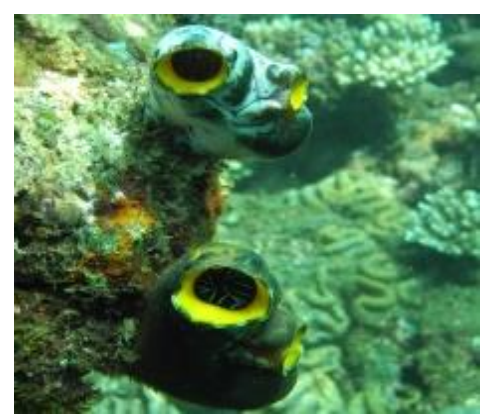

$2 f$.

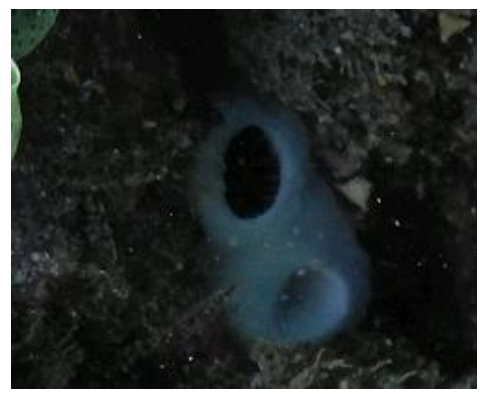

$2 i$.

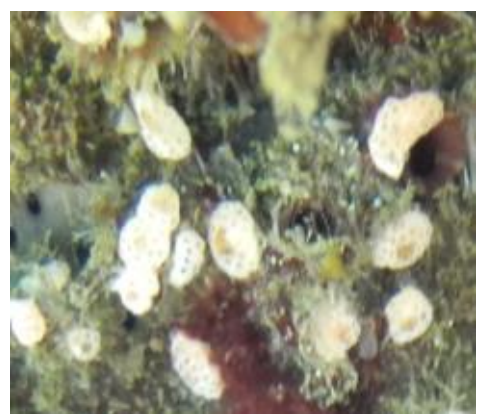

Gambar 2.Jenis-jenis tunikata yang ditemukan di perairan Jemeluk (Didemnum molle (2a), Atriolum robustum (2b), Polycarpa aurata (2c), Polycarpa papillata (2d), Polycarpa sp.(2e), Phallusia sp 1 (2f), Phallusia sp 2.(2g), Rhopalaea sp (2h), Didemnum sp (2i)). 
Rendahnya kelimpahan jenis tunikata di stasiun 2 (Gambar 3) dimungkinkan karena adanya masukan air tawar melalui aliran sungai. Masukan air tawar dapat menurunkan nilai salinitas perairan laut, sedangkan Tunikata merupakan hewan laut sejati yang hanya dapat hidup pada kisaran salinitas 30-32\% (Kott et al. 2009). Salinitas yang bervariasi dapat membatasi distribusi tunikata walaupun terdapat beberapa jenis yang mampu bertahan pada kondisi tersebut (Abrar dan Manuputty, 2008).

Kelimpahan tunikata di stasiun 1 dan 3 perairan Jemeluk (Gambar 3) lebih tinggi namun kedua stasiun ini berbeda signifikan, diduga karena letak kedua stasiun ini teluk dan berdekatan dengan tebing (stasiun 3), sehingga pengaruh arus dan gelombang tidak terlalu besar. Tunikata merupakan hewan sesil maka arus dan gelombang merupakan faktor pembatas distribusi dan kelimpahannya (Edgar et al 2011). Perbedaan kelimpahan jenis tunikata antar ketiga stasiun.

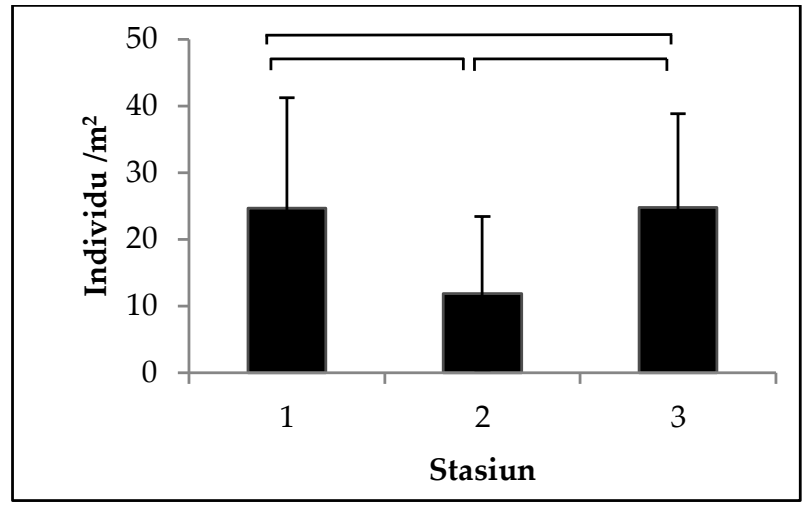

Gambar 3. Kelimpahan tunikata di perairan Jemeluk

Terdapat 9 jenis tunikata di Perairan Penuktukan yaitu Didemnum molle (2a) ,Atriolum robustum (2b), Polycarpa aurata (2c), Polycarpa papillata (2d), Polycarpa sp. (2e), Phallusia sp 01. (2f), Phallusia sp 02. (2g), Didemnum sp. (2i), dan Herdmania momus (2j) (Gambar 4) dimana jenis
$2 a$.

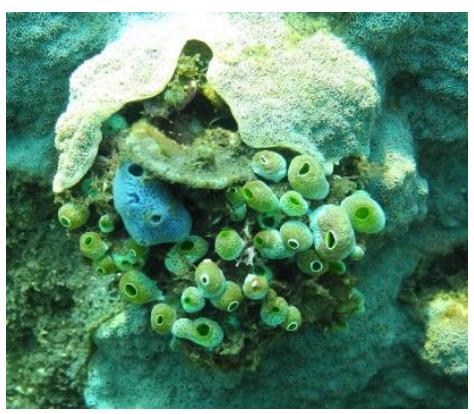

$2 d$.

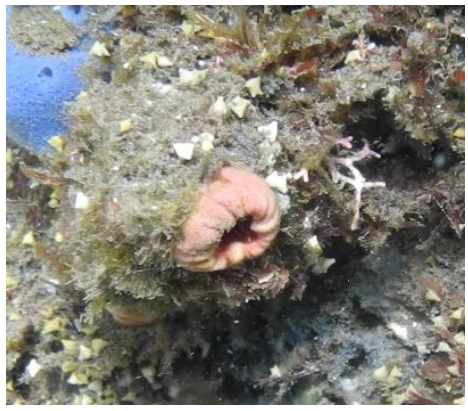

$2 \mathrm{~g}$.

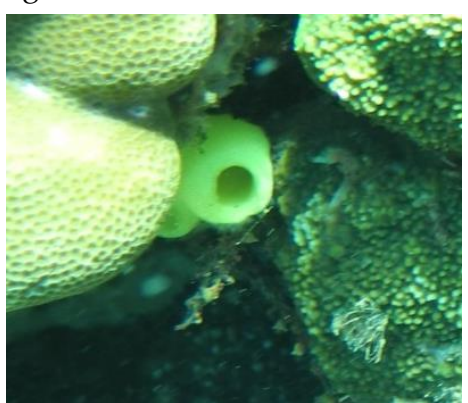

$2 b$.

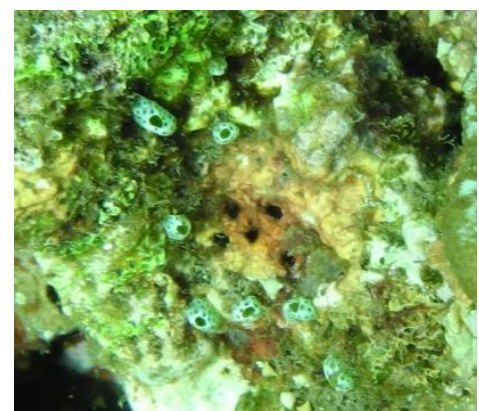

$2 e$.

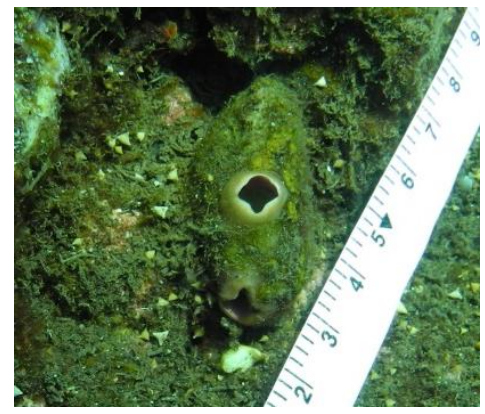

*2.h.

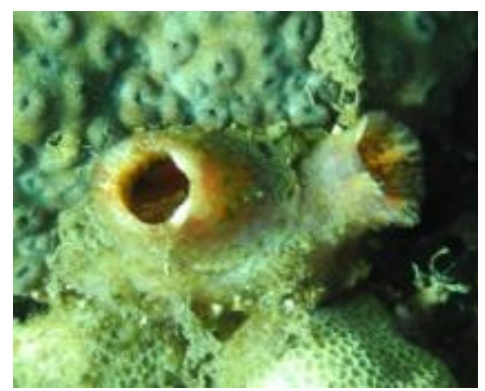

2c.

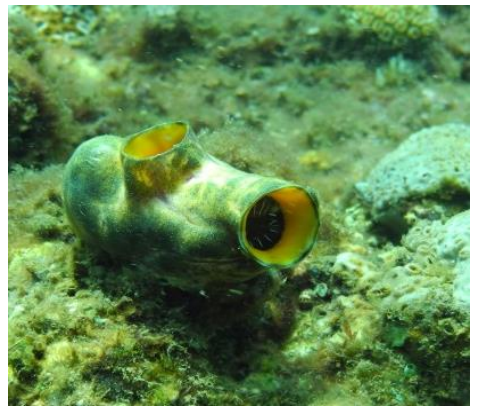

$2 f$.

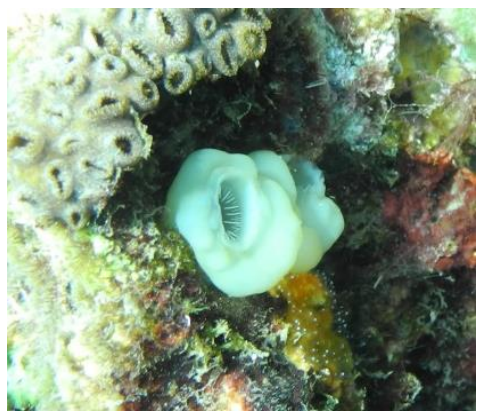

$2 \mathrm{i}$.

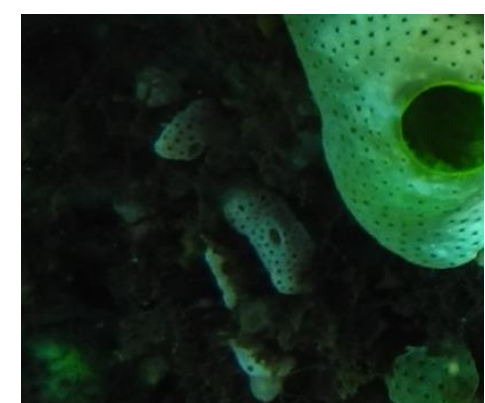

Gambar 4. Jenis-jenis tunikata yang ditemukan di perairan Penuktukan (Didemnum molle (2a), Atriolum robustum (2b), Polycarpa aurata (2c), Polycarpa papillata (2d), Polycarpa sp.(2e), Phallusia sp 1 (2f), Phallusia sp 2.(2g), Herdmania momus (2h), Didemnum sp (2i)) 
Herdmania momus (2j) hanya ditemukan pada Perairan Penuktukan. Hasil kelimpahan jenis ratarata tertinggi terdapat di stasiun 3 dan terendah di stasiun 1 (Gambar 5). Hasil uji statistik Sign Test (Sign Test uji lanjut setelah uji friedman yang menyatakan berbeda nyata, dimana $P_{\text {hit }}>a$ yang berarti h0 di tolak) dengan selang kepercayaan 95\% ( $\mathrm{a}=0.05$ ), didapatkan hasil $\mathrm{P}>\mathrm{a}$ dimana $\mathrm{H} 0$ di tolak yang berarti menunjukkan bahwa terdapat perbedaan nyata kelimpahan antar ketiga stasiun pengamatan. perbedaan kelimpahan jenis tunikata antar ketiga stasiun.

Rendahnya kelimpahan jenis di stasiun 1 perairan Penuktukan (Gambar 5) diduga karena stasiun ini merupakan alur lalu lintas kapal nelayan. Pengaruh arus yang diakibatkan oleh mesin kapal mengakibatkan tunikata mudah terlepas dari substratnya dapat menurunkan kelangsungan hidup tunikata sehingga kelimpahan jenis yang ditemukan di stasiun ini relatif rendah. Tingginya kelimpahan jenis pada stasiun 2 dan 3 perairan Penuktukan (Gambar 5) diduga karena pada kedua stasiun tersebut terdapat karang masive dan sub-masive dalam jumlah yang banyak serta substrat dasar perairan dalam bentuk pecahan karangdan karang mati yang merupakan habitat tunikata. Menurut Edgar et al (2011), kelimpahan tunikata lebih tinggi pada terumbu karang baik yang hidup maupun yang mati, sedangkan kelimpahannya tunikata lebih rendah pada substrat pasir, lumpur dan patahan karang.

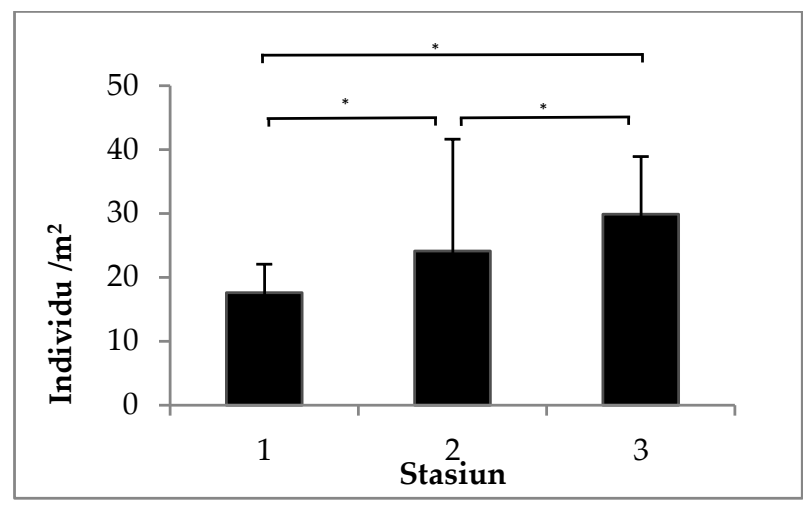

Gambar 5. Kelimpahan tunikata di perairan Penuktukan

\subsection{Komposisi Jenis Tunikata}

Berdasarkan hasil pengamatan komposisi jenis di perairan Jemeluk ditemukan 9 jenis (Tabel 4). Komposisi jenis tunikata pada stasiun 1 ditemukan

\section{Tabel 4}

Komposisi jenis tunikata di perairan Jemeluk

\begin{tabular}{clccc}
\hline No & Jenis & $\begin{array}{c}\text { Stasiun 1 } \\
\text { Jemeluk }\end{array}$ & $\begin{array}{c}\text { Stasiun 2 } \\
\text { Jemeluk }\end{array}$ & $\begin{array}{c}\text { Stasiun 3 } \\
\text { Jemeluk }\end{array}$ \\
\hline 1 & Didemnum molle & 85.65 & 68.79 & 31.80 \\
2 & Atriolum robustum & 13.65 & 30.87 & 0.06 \\
3 & Polycarpa aurata & 0.45 & 0.11 & 0.00 \\
4 & Polycarpa papillata & 0.08 & 0.11 & 0.00 \\
5 & Polycarpa sp & 0.00 & 0.00 & 0.05 \\
6 & Phallusia sp 01 & 0.06 & 0.06 & 0.00 \\
7 & Phallusia $s p$ 02 & 0.04 & 0.00 & 0.00 \\
8 & Rhopalaea $s p$ & 0.06 & 0.00 & 1.91 \\
9 & Didemnum $s p$ & 0.00 & & \\
\hline
\end{tabular}

Tabel 5

Komposisi jenis tunikata di perairan Penuktukan

\begin{tabular}{clccc}
\hline No & Jenis & $\begin{array}{c}\text { Stasiun 1 } \\
\text { Penuktukan }\end{array}$ & $\begin{array}{c}\text { Stasiun 2 } \\
\text { Penuktukan }\end{array}$ & $\begin{array}{c}\text { Stasiun 3 } \\
\text { Penuktukan }\end{array}$ \\
\hline 1 & Didemnum molle & 44.93 & 62.20 & 35.95 \\
2 & Atriolum robustum & 49.14 & 0.72 & 0.49 \\
3 & Polycarpa aurata & 2.58 & 0.22 & 0.18 \\
4 & Polycarpa papillata & 0.46 & 0.33 & 0.38 \\
5 & Polycarpa sp & 0.27 & 0.19 & 0.04 \\
6 & Phallusia sp 01 & 0.46 & 0.11 & 0.04 \\
7 & Phallusia sp 02 & 0.08 & 0.25 & 0.56 \\
8 & Didemnum sp & 2.09 & 0.03 \\
9 & Herdmania momus & 0.00 & 0.02
\end{tabular}


7 jenis yaitu Didemnum molle, Atriolum robustum, Polycarpa aurata, Polycarpa papillata, Phalusia sp 1., Phalusia sp2. dan Rhopalaea sp., pada stasiun 2 ditemukan 6 jenis tunikata yaitu Didemnum molle, Atriolum robustum, Polycarpa aurata, Polycarpa papillata, Polycarpa sp., dan Phallusia sp 2., dan pada stasiun 3 ditemukan 4 jenis tunikata yaitu Didemnum molle, Atriolum robustum, Phallusia sp 1., dan Didemnum molle. Dari ketiga stasiun pengamatan jenis Didemnum molle merupakan jenis yang memiliki nilai yang paling tinggi dari ketiga stasiun dimana pada stasiun 1 yaitu 85,65\%, pada stasiun 2 yaitu 68,79\%, dan pada stasiun 3 yaitu $51,80 \%$. Didemnum molle merupakan hewan yang memiliki kemampuan berkoloni dan memiliki pertumbuhan yang sangat cepat, daya adaptasi yang baik serta dapat dominan di lingkungan dengan bahan organik yang tinggi (Edgar et al, 2011).

Hasil komposisi jensi tunikata pada perairan Penuktukan ditemukan 9 jenis tunikata (Tabel 5). Pada stasiun 1 ditemukan 8 jenis tunikata yaitu Didemnum molle, Atriolum robustum, Polycarpa aurata, Polycarpa papillata, Phalusia sp 1., Phalusia sp 2. dan Didemnum sp. Pada stasiun 2 dan 3 ditemukan 9 jenis tunikata yaitu Didemnum molle, Atriolum robustum, Polycarpa aurata, Polycarpa papillata, Phalusia sp 1., Phalusia sp2., Didemnum sp. dan Herdmania momus. Nilai komposisi jenis tertinggi pada stasiun 1 yaitu pada jenis Atriolum robustum $(44,93 \%)$, pada stasiun 2 yaitu jenis Didemnum molle $(62,20 \%)$, dan pada stasiun 3 pada yaitu jenis Didemnum molle (93,49\%). Dari ketiga stasiun di perairan Penuktukan jenis Didemnum molle dan Atriolum robustum merupakan jenis yang paling banyak ditemukan, hal ini juga di temukan pada penelitian yang dilakukan oleh Abrar dan Manuputty (2008) di perairan Berau, Kalimantan Timur dimana jenis dari family Didemnidae ditemukan lebih banyak dibandingkan family lainnya. Jumlah jenis tunikata yang ditemukan di perairan Jemeluk dan Penuktukan lebih sedikit daripada yang ditemukan oleh Sala et al (2012) di perairan teluk Doreri yaitu sebanyak 12 jenis.

\subsection{Keanekaragaman Tunikata}

Secara umum indeks keanekaragaman di perairan Jemeluk berada dalam kategori indeks keanekaragaman rendah (Gambar 6). Keanekaragaman jenis tertinggi terdapat di stasiun 1 dan $3\left(\mathrm{H}^{\prime}=0.50\right)$ dan terendah pada stasiun 2
$\left(\mathrm{H}^{\prime}=23\right)$ pada perairan Jemeluk (gamabar 6). Rendahnya keanekaragaman tunikata di stasiun 2 pada perairan Jemeluk (gamabr 6) diduga karena adanya aliran sungai yang membawa inputan air tawar ke perairan. Masuknya air tawar ke perairan laut dapat menurunkan salinitas. Salinitas yang berubah-ubah merupakan faktor pembatas sebaran dan keanekaragaman tunikata (Pineda, 2012). Selain itu, toleransi salinitas tunikata yang sempit yaitu 30-32\% diduga penyebab rendahnya jenis tunikata yang dapat hidup pada stasiun ini.

Tingginya keanekaragaman jenis di stasiun 1 dan 3 pada perarain Jemeluk (Gambar 6) diduga karena kedua stasiun tidak terdapat pengaruh air tawar atau memiliki salinitas yang relatif stabil, selain itu letak perairan Jemeluk di Teluk sehingga perairannya lebih terlindung dari pengaruh arus dan gelombang, sehingga memungkinkan lebih banyak tunikata yang dapat hidup.

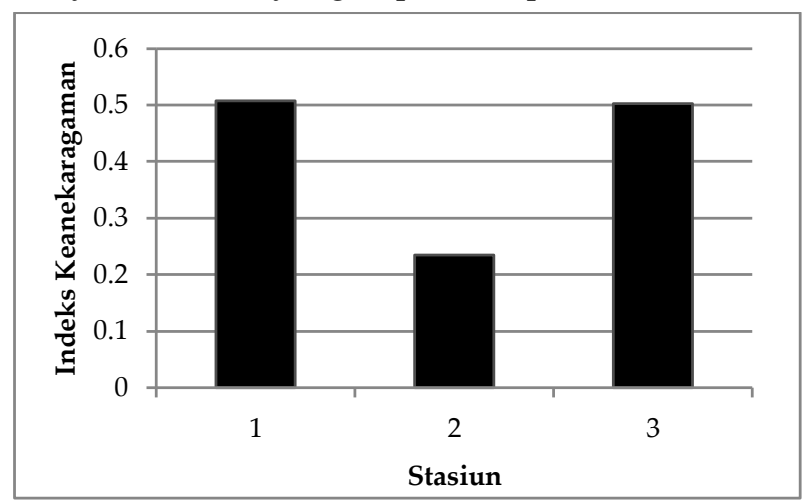

Gambar 6. Keanekaragaman jenis tunikata di perairan Jemeluk

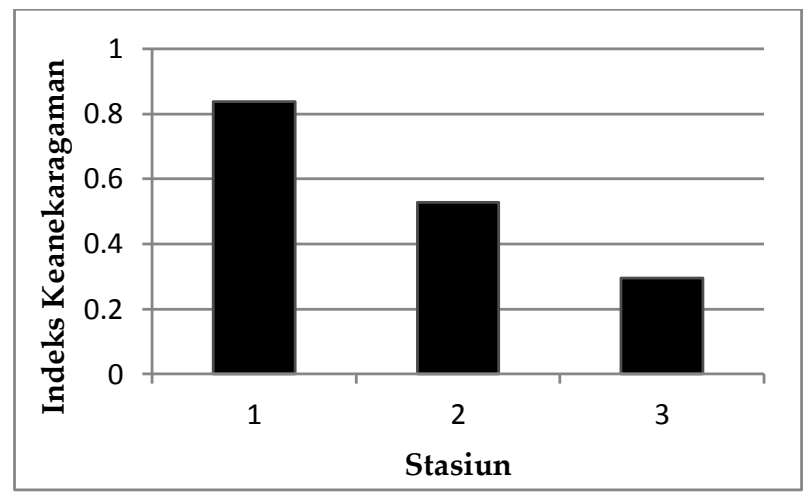

Gambar 7. Keanekaragaman jenis tunikata di perairan Penuktukan

Indeks Keanekaragaman di perairan Penuktukan rata-rata berada dalam kategori indeks keanekaragaman rendah (Gambar 7). Keanekaragaman jenis tertinggi terdapat pada stasiun $1 \quad\left(\mathrm{H}^{\prime}=0.83\right)$ dan terendah di stasiun 3 
$\left(\mathrm{H}^{\prime}=0.29\right)$ pada Perairan Penuktukan (Gambar 7). Secara umum, keanekaragaman jenis di Perairan Penuktukan lebih tinggi dari pada keanekaragaman jenis di Perairan Jemeluk.

Perbedaan kelimpahan dan keanekaragaman ini diduga disebabkan perbedaan geomorfologi terumbu di kedua perairan. Perairan Penuktukan yang merupakan zona lereng terumbu. Zona ini memiliki variasi pasang surut yang lebih stabil, kecepatan arus permukaan dan gelombang yang tinggi pada zona rataan terumbu yang terdapat di Perairan Jemeluk (Morrissey 1980). Selain itu karakteristik substrat di zona lereng terumbu yang berupa pecahan karang merupakan habitat ideal untuk hewan sesil seperti tunikata dibandingkan substrat sedimen yang umum terdapat di zona rataan terumbu (Morrissey, 1980). Namun, kecepatan arus permukaan di kedua perairan sangat lambat, sehingga mendukung kehidupan tunikata yang ditunjukkan dengan keanekaragaman yang lebih tinggi di perairan Penuktukan, walaupun memiliki geomorfologi lereng terumbu. Selain itu, secara umum tingginya keanekaragaman jenis pada setiap stasiun di perairan Penuktukan dari pada perairan Jemeluk dapat disebabkan karena stasiun-stasiun pengamatan di Perairan Penuktukan lebih dalam $( \pm 6 \mathrm{~m})$ dari pada stasiun-stasiun pengamatan di Perairan Jemeluk $( \pm 5 \mathrm{~m})$. Rendahnya indeks keanekaragaman pada kedua perairan diduga di pengaruhi oleh kedalaman, apabila dilakukan sampling lebih dalam lagi kemungkinan keanekaragaman jenis tunikata akan lebih tinggi, seperti penelitian yang dilakukan oleh sala et al (2012) dimana kelimpahahan tunikata lebih banyak ditemukan pada kedalaman 10 meter.

\section{Simpulan}

Kelimpahan tunikata pada perairan Jemeluk tidak berbeda signifikan antar stasiun sedangkan kelimpahan tunikata pada perairan Penuktukan berbeda nyata antar stasiun. Komposisi jenis tunikata di perairan Jemeluk dan Penuktukan sama ditemukan 9 jenis tunikata dimana jenis yang mendominasi dari kedua perairan yaitu jenis Didemnum molle dan Atriolum robustum. Keanekaragaman jenis tunikata pada perairan Jemeluk tertinggi terdapat pada stasiun 1 dan 3. Sedangkan keanekaragaman jenis pada perairan Penuktukan tertinggi terdapat pada stasiun 1. Secara umum indeks keanekaragaman tunikata di kedua perairan dikategorikan rendah.

\section{Ucapan terimakasih}

Penulis mengucapkan terima kasih kepada Laboratorium Ilmu Kelautan, Universitas Udayana, ucapan terima kasih juga disampaikan kepada reviewer yang telah memberikan kritik dan saran dalam penulisan artikel ini, serta Ayu Astini, Febbi Mellani, Raditya Putra yang telah membantu dalam pengambilan data di lapangan.

\section{Daftar Pustaka}

Abrar, M., \& Manuputty, A. E. W. (2008). Inventarisasi dan Sebaran Biota Ascidian di Terumbu Karang Perairan Berau, Kalimantan Timur. Oseanologi dan Lirnnologi di Indonesia, 34, 47-66.

Affan, J. M. (2012). Identifikasi lokasi untuk pengembangan budidaya keramba jaring apung (KJA) berdasarkan faktor lingkungan dan kualitas air di perairan pantai timur Bangka Tengah. DEPIK Jurnal Ilmu-Ilmu Perairan, Pesisir dan Perikanan, 1(1), 78-85.

Ali, H. A. J., Tamilselvi, M., \& Sivakumar, V. (2014). Non-indigenous ascidians in VO Chidambaram port, Thoothukudi India. Indian Journal of Geo-Marine Sciences, 43(11), 2147-2157

Brodie, J. E., Devlin, M., Haynes, D., \& Waterhouse, J. (2011). Assessment of the eutrophication status of the Great Barrier Reef lagoon (Australia). Biogeochemistry, 106(2), 281-302.

Colin, P. L., \& Arneson, C. (1995). Tropical Pacific Invertebrates: A field guide to the marine invertebrates occurring on tropical Pacific coral reefs, sea grass beds and mangroves. Beverly Hills, California, USA: Coral Reef Foundation, Coral Reef Press.

Collen, B., Loh, J., Whitmee, S., McRAE, L., Amin, R., \& Baillie, J. E. M. (2009). Monitoring change in vertebrate abundance: the Living Planet Index. Conservation Biology, 23(2), 317-327.

Da Rocha, R. M., Neves, I. M., \& Gamba, G. A. (2015). New species of Didemnidae (Tunicata: Ascidiacea) from the tropical coast of Brazil. Zootaxa, 3905(3), 381396.

Djarwanto, P. S. (1991). Statistik Non Parametrik. (Edisi ke-2). Yogyakarta, Indonesia: Badan Penerbit Fakultas Ekonomi (BPFE) Universitas Gadjah Mada (UGM).

Edgar, G. J., Banks, S. A., Bessudo, S., Cortés, J., Guzmán, H. M., Henderson, S., Martinez, C., Rivera, F., Soler, G., Ruiz, D., \& Zapata, F. A. (2011). Variation in reef fish and invertebrate communities with level of protection from fishing across the Eastern Tropical Pacific seascape. Global Ecology and Biogeography, 20(5), 730-743 
Gewing, M. T., Bronstein, O., Nagar, L. R., Granot, I., Frid, O., \& Shenkar, N. (2016). First record of the nonindigenous ascidian Microcosmus exasperatus, Heller 1878, in Cyprus. Marine Biodiversity, 46(4), 937-941.

Gischler, E. (2010). Indo-Pacific and Atlantic spurs and grooves revisited: the possible effects of different Holocene sea-level history, exposure, and reef accretion rate in the shallow fore reef. Facies, 56(2), 173-177.

Hirose, E., Ohtake, S. I., \& Azumi, K. (2009). Morphological characterization of the tunic in the edible ascidian, Halocynthia roretzi (Drasche), with remarks on 'soft tunic syndrome'in aquaculture. Journal of fish diseases, 32(5), 433-445.

Kott, P. (2009). Taxonomic revision of Ascidiacea (Tunicata) from the upper continental slope off northwestern Australia. Journal of Natural History, 43(31-32), 1947-1986.

Lambert, G., Karney, R. C., Rhee, W. Y., \& Carman, M. R. (2016). Wild and cultured edible tunicates: a review. Management of Biological Invasions, 7(1), 59-66.

Lambert, G., Shenkar, N., \& Swalla, B. J. (2010). First Pacific record of the north Atlantic ascidian Molgula citrina-bioinvasion or circumpolar distribution. Aquatic Invasions, 5(4), 369-378.

Morrissey, J. (1980). Community structure and zonation of microalgae and hermatypic corals on a fringing reef flat of magnetic island (Queensland, Australia). Aquatic Botany, 8, 91-139.

Pineda, M. C., Turon, X., \& López-Legentil, S. (2012). Stress levels over time in the introduced ascidian Styela plicata: the effects of temperature and salinity variations on hsp70 gene expression. Cell Stress and Chaperones, 17(4), 435-444.

Poore, G. C., Avery, L., Błażewicz-Paszkowycz, M., Browne, J., Bruce, N. L., Gerken, S., Glasby, C., Greaves, E., McCallum, A. W., Staples, D., Syme, A., Taylor, J., Walker-Smith, G., Warne, M., Watson, C., Williams, A., Wilson, R. S., \& Woolley, S. (2015). Invertebrate diversity of the unexplored marine western margin of Australia: taxonomy and implications for global biodiversity. Marine Biodiversity, 45(2), 271-286.

Radhalakshmi, R., Sivakumar, V., \& Ali, H. A. J. (2014). Analysis of selected species of ascidians as bioindicators of metals in marine ecosystem. International Journal of Current Microbiology and Applied Sciences, 3(8), 755-764.

Roberts, D. A., Johnston, E. L., \& Knott, N. A. (2010). Impacts of desalination plant discharges on the marine environment: A critical review of published studies. Water Research, 44(18), 5117-5128.

Rukminasari, N., Nadiarti, N., \& Awaluddin, K. (2016). Pengaruh Derajat Keasaman ( $\mathrm{pH}$ ) Air Laut Terhadap Konsentrasi Kalsium dan Laju Pertumbuhan halimeda sp. Torani Jurnal Ilmu Kelautan dan Perikanan, 24(1), 2834.

Sala, R., Tururaja, T., \& Mampioper, X. (2012). Distribusi Ascidian Berdasarkan Kedalaman Perairan Di Kawasan Terumbu Karang Teluk Doreri Manokwari. Dalam Prosiding Seminar Nasional Tahunan IX Hasil-Hasil Penelitian Perikanan dan Kelautan. Yogyakarta, Indonesia, 14 Juli 2012.

Sugiyono, S. (2007). Statistika Untuk Penelitian. (Cetakan ke 11). Bandung, Indonesia: CV Alfabeta.

(C) 2018 by the authors; licensee Udayana University, Indonesia. This article is an open access article distributed under the terms and conditions of the Creative Commons Attribution license (http://creativecommons.org/licenses/by/3.0/). 